\title{
Non- point Source Pollution Load Calculation Based on Raster Data and Export Coefficient Model
}

\author{
Longxi $\mathrm{Han}^{1,2}$, Qi Gao², Fei Huo ${ }^{3}$ \\ ${ }^{1}$ Key Laboratory of Shallow Lakes of Ministry of Education, Hohai University, Nanjing 210098, China; \\ ${ }^{2}$ College of Environment, Hohai University. Nanjing 210098, China; \\ ${ }^{3}$ Sinopec Nanjing Engineering\&Construction Incorporation ,Nanjing 211100, China.
}

\begin{abstract}
The article is focused on the surrounding land area of Zhihugang of Taihu Basin, the study area was divided into square grid of $100 \mathrm{~m}$ on a side, all grid units land use types attribute values were identified according to the regional land use types, raster data model applied to land-use information was set up. Export coefficient of the total nitrogen (TN hereafter) and total phosphorus (TP hereafter) in different land types of non-point source (NPS hereafter) pollution was confirmed synthesizable, the NPS pollutant yielding model based on raster data model was set up, as a result TN and TP load in non-point source pollution was obtained by computation.
\end{abstract}

Keywords-NPS pollution; export coefficient model; raster data; taihulake.

\section{INTRODUCTION}

Compared with point source pollution, NPS pollution has the characteristics of randomness of occurring time, intermittency of occurring mode, complexity of the mechanism process, uncertainty of the discharge path and value, spatial variability of pollution load, and difficulty of monitoring simulation and control etc. [1]. Export coefficient method, based on different land use types of pollutants export coefficient and land use status, establishes mathematical relationship between receiving pollution load of environmental water and regional land use types directly, greatly simplifies the complex forming process of NPS pollution. Compared to mathematical model based on physical mechanisms, it requires fewer parameters, has a certain level of accuracy and extensive applicability. In recent years, NPS pollution research based on export coefficient method is mainly focused on two aspects, first, the determination of the pollutants productivity of different land use types, some typical relevant achievements has been gotten as followed: Li et al. [2] took zhexi hydraulic region of Taihu basin as the research area, selected small watershed based more on single land-use type, used the synchronous monitoring of water quality and quantity to determine the runoff pollutants concentration of different land use types; Chao Gao [3]conducted pollution source survey and made field observation to determine fertilizer input and loss rate, in order to estimate pollutants productivity of different land use types; Shao-ping Wang [4] monitored typical district to determine relationship between different land use types and NPS pollution load, then estimated the NPS pollution load.
On the other hand, the use of technical measures, such as RS (remote sensing), and GIS (geographic information systems), improved the estimating precision of the watershed pollution load, and has got some typical research achievements as followed: Jin et al[5] used TWEIM remote sensing to interpret land use data, analyzed the effects of Taihu Basin land-use change on the NPS pollution load; $\mathrm{Li}$ et al [6]refined the distribution of land use in a basin and established a semi-distributed export coefficient model to calculate the nutrient loads in the Xitiaoxi region of Taihu Basin using a GIS system.

The article was focused on the surrounding land area of Zhihugang of Taihu Basin, based on raster data model and NPS pollutants pollution yielding model, as a result TN and TP load in non-point source pollutionwas obtained by computation.

\section{STUDY AREA}

The study area is located in Wuxi city, Jiangsu province, China. It covers the river system centering at the harbour Zhihugang, with the harbour Wujingang as the western boundary, Yangxi river as the eastern boundary, the BeijingHangzhou Grand Canal as the northern boundary and Taihu Lake as the southern boundary, as shown in Fig.1.

The landscape of the study area is relatively flat. In this region, the agricultural industry is developed, with a large amount of paddy fields and orchards. So the agriculture derived NPS pollution is responsible for the local environmental problem. Also, the urban NPS pollution plays an un-negligible role in the pollution to waters, which comes from the cities and towns situated to the north and northeast of the area. 


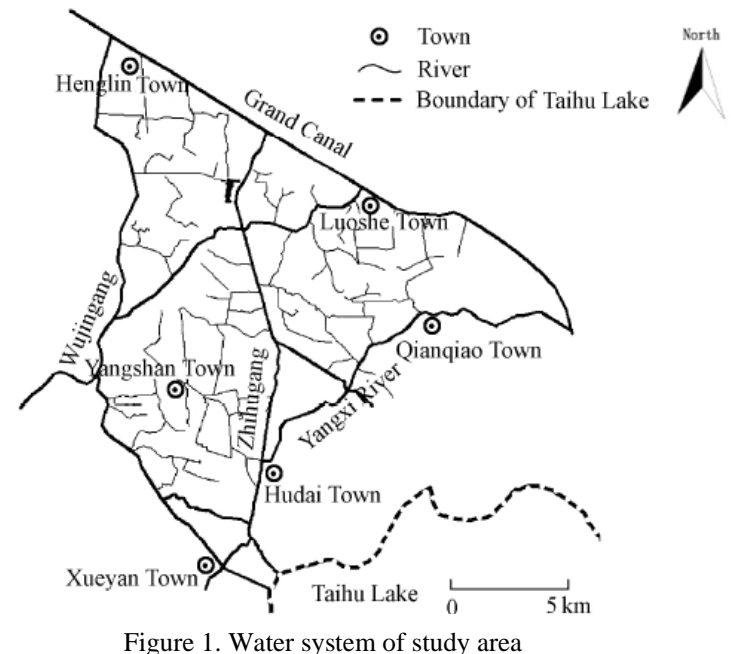

III. THE ESTABLISHMENT OF LAND-USE INFORMATION RASTER DATA MODEL

The land-use information mainly included land use types and the integrated distribution characteristics. From 2008 TM/ETM images, man-machine interactive visual interpretation was used to get the land use information. Considering real situation of Taihu Basin and the possibility of image interpretation, the research area was divided into four types of land use. They were paddy field, farmland (vegetable field and orchard), water surface (lake, streamside and fish pond) and build-up land (roads and large villages), respectively. In order to apply NPS export coefficient model, it was need to rasterize study area of land use information and build raster data model. Raster grid data model displayed information selectively, acceptedpositioning information and stored the realistic information by regular grid. The modeling process included raster data sampling and encoding. Among them, raster data sampling process: (a) selected regular grid to cover the earth surface, (b) conducted space sampling, (c) selected grid attribute values average, central point average, or one of angular points attribute values as the grid attribute values; Raster data encoding included: (a) divided raster data layers, made that each raster data layer had a unique attribute value, (b) specified attribute values of each grid, (c) established relationship between the grid attribute values and the database management system.

As a popular drawing tool, AutoCAD has powerful spatial computation ability and mature methods of secondary development, Its function of setting up layer and management can satisfy the demand of dividing raster data layers, the coordinate attributes of primitive itself and extended data (and extended record), which can be added by users, can store the attribute information of each grid. By developing custom applications using Objec-tARX, some functionalities could be achieved, such as reading attributes, area computation, overlay analysis, and proximity analysis etc. Therefore, AutoCAD was selected as the platform for building raster data model, the specific build process as followed: a. Imported and registrated data sources. Remote-sensing images were imported into AutoCAD in the grating form. A specific handler was used for registration according to latitude and longitude of landmark points.

b Generated raster layer. In order to approximate land spatial distribution characteristics effectively to guarantee precision, used square cells of $100 \mathrm{~m} \times 100 \mathrm{~m}$ to generate the raster layer covering the study area.

c. Specified land use attribute value of each grid. With the method of man-machine interactive visual interpretation, the land use type of the grid central sample point was made the grid land use attribute, which was added into extended data of grid primitive. The land use type in one cell could be treated as a single type. For instance, if the grid central sample point was located in paddy field area in the satellite map, the whole grid land use attributes would be specified paddy field.

d. Divided raster data layers, and made sure that each raster data layer had a unique attribute value. There were four layers in total, they are paddy field, farmland, water surface and build-up land. A specific handler was used to move grid primitive that had the same land use property to the corresponding layer. For instance, if the grid land use attribute was paddy field, it would be moved to the paddy field layer. The main purpose of this step was to make it easy for extracting, displaying and statistic of the land use information.

TABLE I. AREA OF FOUR LAND USE TYPES

\begin{tabular}{ccc}
\hline Land use types & Grid number & Area $\left(\mathrm{km}^{2}\right)$ \\
\hline Farmland & 6719 & 67.19 \\
Built-up land & 6311 & 63.11 \\
Paddy field & 4992 & 49.92 \\
Water surface & 2793 & 27.93 \\
\hline
\end{tabular}

After building raster data model, counted the grid number of paddy field, farmland, water surface and build-up land respectively in study area, then converted grid number to area in a grid size of $100 \mathrm{~m} \times 100 \mathrm{~m}$. Area of various land use types in study area is shown in table 1, spatial distribution of land use types is shown in Fig.2. The statistical results show that in study area, farmland area is the largest, makes up about $32.28 \%$ of the total area, which is mainly distributed in the midstream and northern area of the Zhihugang; build-up land area accounts for $30.32 \%$, which is mainly distributed in the northern and northeastern lake; paddy field area accounts for $23.98 \%$, which is mainly distributed in the upstream and downstream Zhihugang; water surface accounts for $13.42 \%$, which is mainly distributed in the upstream Zhihugang. 


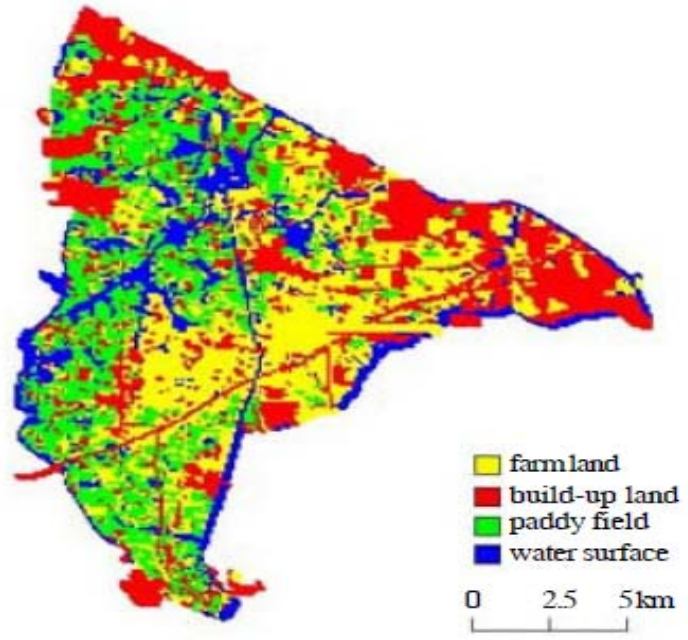

Figure 2. Spatial distribution of land use types.

IV. THE SELECTION OF EXPORT COEFFICIENT MODEL AND EXPORT COEFFICIENT

\section{A. Model structure}

This study adopted the export coefficient model to calculate average annual production of NPS pollution in each cell. The model takes into account the relationship between production of NPS pollution and land use types, which is established directly by the land use types and export coefficient. The expression is

$$
L_{j}=\sum_{i=1}^{n} a_{i j} A_{i j}
$$

Where $L_{j}$ is the total load of pollutant $j, \mathrm{~kg} / \mathrm{a}$;

nis the number of land use types and its value is 4 in this study;

$A_{i}$ is the area of land use type $i$ in the calculation cell, $\mathrm{hm}^{2}$;

$a_{i j}$ is the export coefficient of pollutant $j$ from land use type $i, \mathrm{~kg} /\left(\mathrm{hm}^{2} \cdot \mathrm{a}\right)$.

For practical use, smaller cell is used to make the land use type in each cell singular, then, land use type of central point in cell can serve asland use type attribute of whole unit. This method greatly simplifiescomputation steps, and $A_{i}$ is area of cell of $i$.

\section{B. The selection of export coefficient value}

It is essential to define the value of export coefficient. The value can be affected by many factors, such as underlying surface, hydrological characteristics, vegetative condition and cultivating mode. Therefore, the acquirement of export coefficient that matches regional features is the key to using the export coefficient model. A lot of researches on export coefficient have been done in plain river network of Taihu basin the study area. [7-10]

In general, export coefficient values are derived from field data, sometimes estimated from a literature review, so in this study the results obtained from experimental analysis in a small watershed around Taihu Lake can be used for reference. The Export coefficient of the four following land use types are showed in Table 2.
TABLE II. USED EXPORT COEFFICIENT VALUES OF FOURLAND USE TYPES.

\begin{tabular}{ccc}
\hline \multirow{2}{*}{ Land use types } & \multicolumn{2}{c}{ Export coefficient $\left(\mathrm{kg} / \mathrm{hm}^{2} \cdot \mathrm{a}\right)$} \\
\cline { 2 - 3 } & $\mathrm{TN}$ & $\mathrm{TP}$ \\
\hline Farmland & 14.52 & 4.05 \\
Built-up land & 20.00 & 6.00 \\
Paddy field & 34.10 & 1.75 \\
Water surface & 21.96 & 1.99 \\
\hline
\end{tabular}

\section{V.ESTIMATION AND ANALYSIS OF NPS POLLUTION ANNUAL LOAD IN STUDY AREA}

Extracted the land use information applied to raster data model. Used the export coefficient method to estimate the regional annual NPS pollution load and average export coefficient.

The TN load of study area is $455.34 \mathrm{t} /$ year, average export coefficient is $21.88 \mathrm{~kg} /\left(\mathrm{hm}^{2} \cdot \mathrm{a}\right)$. The proportions of TN exported from the four land use types are $38 \%, 28 \%, 21 \%$, and $13 \%$, respectively, for paddy field, built-up land, farmland, and water surface; the TP load of study area is $79.371 \mathrm{t} /$ year, average export coefficient is $3.81 \mathrm{~kg} /\left(\mathrm{hm}^{2} \cdot \mathrm{a}\right)$ The proportions of TP exported from the four land use types are $11 \%, 48 \%, 34 \%$, and $7 \%$, respectively. According to these results, the main sources of TN and TP are identified: the paddy field contributes most to the TN load, and the built-up land contributes most to the TP load.

TABLE III. TN LOADS AND TP LOADS OF FOUR LAND USE TYPES.

\begin{tabular}{ccc}
\hline \multirow{2}{*}{ Land use types } & \multicolumn{2}{c}{ Pollution load (t/year) } \\
\cline { 2 - 3 } & $\mathrm{TN}$ & $\mathrm{TP}$ \\
\hline Paddy field & 170.23 & 8.73 \\
Built-up land & 126.22 & 37.87 \\
Farmland & 97.56 & 27.21 \\
Water surface & 61.33 & 5.56
\end{tabular}

\section{CONCLUSION}

a. In order to apply NPS pollution export coefficient model, used man-machine interactive visual interpretation from $2008 \mathrm{TM} / \mathrm{ETM}$ images to get the land use information and built raster data model, displayed and stored image data for land use information.

b. Through consulting relevant literature materials, analyzed the studies on nutrient export coefficient in Taihu basin conducted by many experts. As a result,TN, TP export coefficient of four land use types were obtained.

c. Estimated NPS pollution load in Zhihugang area using export coefficient model. Annual TN load and TP load were determined to $455.34 \mathrm{t}$ and $79.37 \mathrm{t}$ respectively.

\section{REFERENCES}

[1] Li hong-Xue, Lin zhang-Yang, The research progress of non-point source pollution export coefficient model. Journal of Ecology, 28(4), pp.755-761, 2009

[2] Hengpeng-Li, Xiao mei-Liu, Wen yu-Huang, Non-point source pollution exportof different land use types in zhexi hydraulic region of Taihu basin. Geography Journal, 59(3), pp.401-408, 2004. 
[3] Chao Gao, Jian guo-Zhu, Yi jian-Dou. The influence of agricultural nonpoint source pollution on water quality of Taihulake, Resources and Environment in the Yangtze Basin, 11(3), pp.260-263, 2002.

[4] Shao ping-Wang. Suzhou creek non-point source pollution load study, Research of Environmental Sciences, 15 (6), pp.20-27. 2002,

[5] Hengpeng-Li, Jinlian-Li, Taihu basin The influence of land use change on non-point source pollution load, Journal of Agro-environment Science, 26 (4) , pp.1214-1218, 2007.

[6] Zhao fu-Li, Guishan-Yang, Hengpeng-Li. Nutrient export estimation of the basin based on the improved export coefficient model, Environmental Science, 30(3), pp.668-672, 2009.
[7] Lin zhang-Yang, De jian-Wang, Li zhong-Xia. The characteristics and controlling ways of agricultural non-point source pollution in Taihu basin, China Water Resources, (20), pp.29-30. 2004.

[8] Li hong-Xue, Lin zhang-Yang, The research progress of non-point source pollution export coefficient model, Journal of Ecology, 28 (4), pp.755-761, 2009.

[9] Liang Duan, Zeng qiang-Duan, Si Qing-Xia, The quantitative research of farmland non-point source pollution in Taihulake, Soil and Water Conservation Bulletin, 26(6), pp.4043, 2006.

[10] Li zhong-Xia, Lin zhang-Yang, Chun jia-Wu, et al. The research of rainfall-runoff $\mathrm{N}, \mathrm{P}$ spatial distribution load of , small typical l town in Taihu area Journal of Agro-environment Science, 22(3), pp.267-270, 2003. 